\title{
Unsustainable Land Use due to 'Catching Up' Investment Pursuits in Ethiopia: The Need for Planning, Zoning and other Regulations
}

Zbelo Haileslasie *

\begin{abstract}
Zoning and land use regulations accommodate and balance various interests which relate to urbanization, food security, enhanced livelihoods, industrialization and globalization, in the context of sustainable development. Unlike comparative practices in other countries, Ethiopia has no comprehensive and codified zoning law even though the zoning stage affects the subsequent stages. Ethiopia has not yet issued an integrated national land use policy. There is also a rush toward massive acquisition of land for investments and proliferation of industrial parks. This is clearly meant to catch up with the plans and aspirations under Ethiopia's Growth and Transformation Plan (GTP) I and II. This article examines the relevant laws and the rush toward land acquisitions and the haphazard decisions thereof vis-à-vis the need for sustainability through a multimodal and integrationist approach. There are constitutional issues with regard to decentralizing local development plans and land administration versus centralizing tendencies in land-investment administration and designation of industrial parks. It is argued that there are gaps in the three-tier stages of (i) Planning and Zoning, (ii) Acquisition and (iii) Performance Requirements, thereby necessitating reform towards the integrated and balanced implementation of these three stages. The political commitment for 'catching up' pursuits should not be at the expense of constitutional rights and issues of sustainability. There is thus the need for an informed decision-making process that accommodates multitude of interests.
\end{abstract}

\section{Key terms}

Land use · Zoning law · Expropriation · Sustainability · Peri-urbans · Industrial park

DOI http://dx.doi.org/10.4314/mlr.v12i1.7

Received: 17 March 2018

Accepted: 7 September 2018

This article is licensed under a Creative Commons Attribution-NonCommercialNoDerivs (CC BY-NC-ND)

\footnotetext{
* Zbelo Haileslassie Embaye (BA in Sociology, LLB, LLM in Tax and Investment Laws, PhD Candidate); Lecturer at Mekelle University, School of Law.

Email: zbelo40@gmail.com
} 


\section{Introduction}

The world is experiencing new human-to-land relations and antecedents. There is dynamism in the evolution and relationship of each category. ${ }^{1}$ These antecedents are the outcomes of globalization, industrialization and urbanization, and they create different conflicts over land. ${ }^{2}$ The global actors including governments pursue various policies and strategies on how to create suitable environment for human wellbeing and different economic activities. In this regard, industrialization is an inevitable economic path to all countries. ${ }^{3}$ This requires good land administration system and holistic impact assessments.

Land use and land development are elements of land administration systems. ${ }^{4}$ The land use element includes setting land use control and policies of spatial and planning issues. The land development activities include regulating and implementing land use plans, construction and giving of permits. ${ }^{5}$ These are made with the interaction of the land tenure and land value parts of the land administration system aiming to bring an efficient land administration system. ${ }^{6}$

However, studies, especially in developing countries, show that most governments strive to catch up with all plans and aspirations without taking feedback from previous interventions. ${ }^{7}$ This has negative implication to the overall goals of sustainable development. These aspirations are attached with the ideologies and political economy narratives that land acquisitions should be undertaken for the fulfillment of investment purposes and plans without considering sustainable land use planning and zoning.

Although the practices may vary globally, the introduction of land use planning and zoning has longer history. ${ }^{8}$ The planning and zoning stage determines land acquisition. There are common experiences of land acquisition

\footnotetext{
${ }^{1}$ P. van der Molen (2002), 'The Dynamic Aspect of Land Administration: An Oftenforgotten Component in System Design, Computers', Environment and Urban Systems26, pp. 361-381.

2 See for example, Yehua Dennis Wei and Xinyue Ye (2014) 'Urbanization, urban land expansion and environmental change in China', Stoch Environ Res Risk Assess 28, pp,757765 China's experience on globalization, development and land urbanization is dealt emphatically.

${ }^{3}$ W. W. Rostow (1960), The Stages of Economic Growth: A Non-Communist Manifesto. Cambridge University Press.

${ }^{4}$ Ian P. Williamson (2000), 'Best Practices For Land Administration Systems In Developing Countries', International Conference On Land Policy Reform, Jakarta, 25-27 July 2000, Lap-C Project Support For Long Term Development of Land Management Policies.

${ }^{5}$ Ibid.

${ }^{6}$ Ibid.

${ }^{7}$ Id., p. 7.

${ }^{8}$ See for example, Patricia E. Salkin (2004), 'Environmental Justice and Land Use Planning and Zoning', Touro Law Center, 32 Real Est. L.J. 429.
} 
that are made based on a set of comprehensive urban plans and zoning ordinances. To this end, laws and standards set forth performance requirements. Like most of the African states, Ethiopia has been using land "... in unplanned and uncontrolled fashion without due regard to the land's best potential use and without due consideration for conservation of natural resources and safeguarding the environment". 9 The rate of urbanization and the expansion of different land uses for various economic activities have been large and very fast. The change is also occurring without due consideration to the potential land use and plans where undesirable environmental and social consequences are exhibited because of the conversion of arable lands, grasslands, and forest areas to urban centers and industrial sites. ${ }^{10}$

Ethiopia has a short history in urban planning and its implementation. ${ }^{11}$ Study reports show that nearly a quarter of the 'recognized urban centers' do not have guiding plans of spatial development and those holding the plans are also found to have difficulty in implementation. ${ }^{12}$ Beyond the factors of poverty and underdevelopment, lack of qualified personnel, standards for planning, and proper legal frameworks for preparing and implementing urban plans are identified as main factors. ${ }^{13}$ GTP-II identifies challenges in this regard which include problems of malpractices in land use, administration and governance.

Ethiopia's industrial policies and strategies focus on assuring the transition from agricultural led economy to industrial led economy. The establishment of government based industrial development zones or industrial parks are also sought to be the primary tools of the economy. ${ }^{14}$ There were two Industrial zones constructed in GTP-I and eight industrial parks are under construction. ${ }^{15}$

${ }^{9}$ Zemen Haddis et al. (2017), 'Ethiopia's Move to a National Integrated Land Use Policy and Land Use Plan', Paper Prepared for Presentation at the 2017 World Bank Conference on Land and Poverty, The World Bank - Washington DC, p. ii, March 20-24, 2017.

${ }^{10}$ Id., p. 1.

${ }^{11}$ SCRIBD, Urban Planning and Implementation Manual, p,3 available at https://www.scribd.com/document/90783198/Urban-Planning-and-ImplementationManual . Accessed on $15 \mathrm{Dec}, 2017$. See, for example, Ministry of Urban Development, Housing and Construction(2010), 'Manual for the Preparation and Implementation of Basic Plans (Structure Plans) of Small Towns of Ethiopia', available at

${ }^{12}$ Ibid www.mwud.gov.et/c/document_library/ Accessed on 12 Jan, 2018.

${ }^{13} \mathrm{Ibid}$

${ }^{14}$ Alebel Bayrau et al. (2017), 'Study on Industrial Park Development: Issues, Practices and Lessons for Ethiopia', Ethiopian Development Research Institute, Research Report 29, available at <www.edri.org.et/Resources/Research_Reports/Research_Report_029>. Accessed on 16 December 2017.

${ }^{15}$ Federal and Democratic Republic of Ethiopia, Growth and Transformation Plan II (GTP II) $(2015 / 16-2019 / 20$. 
The construction and inauguration of such industrial parks is being carried out in a massive scale and number. This is meant to increase the surge of foreign and domestic investors and increase hard currency revenue of USD 1 Billion and ETB 50.2 from each park. ${ }^{16}$

The construction and leasing of such industrial parks is done without a comprehensive land use policy and regulatory frameworks. ${ }^{17}$ The problem of 'catching up' with development goals in various developing countries is now being exhibited in Ethiopia. ${ }^{18}$ However, this should not compromise the concerns for the sustainability of economic gains, social wellbeing and the environment. For instance, it is public knowledge that some of the industrial parks are being criticized by various stakeholders.

This article addresses the theoretical aspects of zoning and discusses whether Ethiopia has zoning law. The article discusses the legal regime in light of the three stages (zoning and planning, acquisition, and performance requirement) with a view to promoting land use sustainability and striking the balance of interests. The other themes of the article include practices in the current (de jure vs. de facto industrial parks and zones), and land acquisition and performance requirement to promote land use sustainability. The analysis includes laws, the theoretical and conceptual frameworks (including comparative experience and good practices), relevant reports, documents, and policies.

\section{Conceptual Framework}

Hans Blumenfeld uses a clear conceptual framework of land use. ${ }^{19}$ His article is relevant in analyzing the contemporary land use planning and zoning issues in Ethiopia. Based on Blumenfeld's framework, this article involves three themes. First, it discusses land use classifications into developed and vacant land. Then, the second division applies to the ownership criterion and it classifies developed land into private and public ownerships. Zoning and community planning are also examples of each division. The third division classifies the privately developed land or zoning into six categories: single, two and multiple families, residential, commercial, light and heavy industry land uses. The latter three

${ }^{16}$ See, for example, the GTP-I and GTP-II, p. 149.

${ }^{17}$ GTP-II, p. 87.

${ }^{18}$ See for example, Ethiopian Investment Commission (2015), ETHIOPIA: A preferred location for foreign direct investment in Africa, An investment guide to Ethiopia. Available at $<\mathrm{http}: / / \mathrm{www}$.investethiopia.gov.et/index.php/informationcenter/publications.htm>. Accessed on Nov, 2017.

${ }^{19}$ Hans Blumenfeld (1962), 'The conceptual framework of land use', Ekistics, Vol. 14, No. 85, pp. 259-263. 
connote the purpose of land use. Under the vacant land category, an agricultural land is taken as an example. ${ }^{20}$

There is also an argument that land use classification should have four criteria, i.e. (i) building and other improvements on land, (ii) occupants or users of land, (iii) major purpose of occupancy of the land, and (iv) kind of activities undertaken on land. The third criterion (major purpose) requires the purpose of establishment and it can be for business or non-business establishment.

The above land use classifications, developed by Blumenfeld in 1962 have a set of two broad criteria that are 'internal consistency' and 'ability to include new phenomena'. Both accommodate issues of 'compatibility and dynamism' respectively in all land use classifications. Blumenfeld suggests that 'many aspects of land use classifications' should be adhered. Accordingly, there are five broad dimensions or aspects of classification criteria. These are: (i) function of establishment; (ii) kind of development; (iii) size and general site development: degree and intensity; and (iv) activity effects of quantitative and qualitative aspects, i.e., the social, environmental and economic impact.

Government interventions on land use may not enable optimal benefits in the absence of zoning, planning, sustainable acquisition and performance. In zoning, there is the need for community planning towards best "land use pattern" and maximization of the benefits. ${ }^{21}$ Community planning is also destined to protect the 'present and future neighbors' by enhancing environmental amenities and aesthetics. This embodies the concerns and objectives of sustainable development. ${ }^{22}$ The sustainable development framework should thus be used in all land use classifications or zoning and planning, acquisitions, performance, and generally balancing of interests.

The contemporary land use classification and urbanization management tools such as Smart Growth and New Urbanisms (especially for suburbanites and residents of urban areas) also reiterates the above criteria and tools of zoning. ${ }^{23}$ They are used as growth and urban sprawl management tools in complementing efforts to promote sustainability.

This article uses a framework that conceptualizes the flow of the analysis into three stages, i.e. (i) the zoning and planning stage, (ii) the land acquisition

\footnotetext{
${ }^{20}$ Id., p, 259.

${ }^{21}$ Id., p. 260.

${ }^{22}$ See for example, Paul De Wit and Willy Verheye (2007), 'Land Use Planning for Sustainable Development', UNESCO-EOLSS Sample Chapters, Land Use, Land Cover. And Soil Sciences- Vol. III

${ }^{23}$ Gerrit Knaap and Emily Talen (2005), 'New Urbanism and Smart Growth: A Few Words from the Academy', International Regional Science Review 28, 2, pp. 107-118.
} 
mechanisms stage and (iii) the performance requirements stage. These stages explore the sustainable use of land and balance competing interests in the context of Ethiopian laws and practices. The first stage (i.e. zoning and planning) is a sine qua non condition to the other stages.

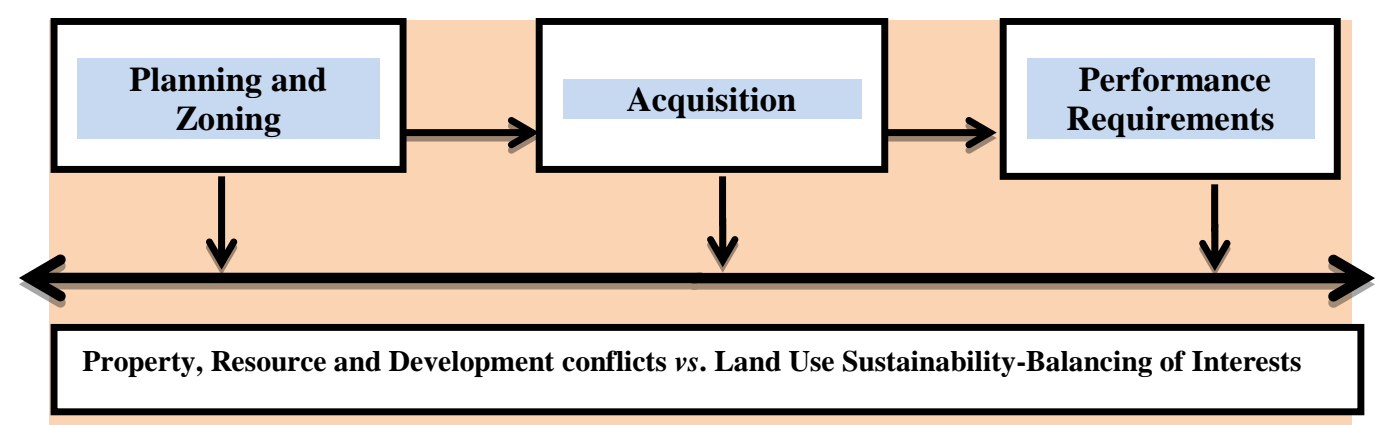

Figure: 1 The three stage model as an analytical framework of the themes and their corresponding tensions. Author's framework.

Figure 1 shows the three stages model in which the sustainability of land use regulatory frameworks and practices in relation with their implication to land use sustainability, and the extent to which competing interests are accommodated and balanced. Careful, sustainable and predictable planning and zoning indeed accommodates various interests and avoids urban sprawl. ${ }^{24}$ The framework for the three stages is used to examine Ethiopia's laws and practices on zoning and urban planning, industrial parks, rural and urban land, environmental protection and investment, along with their application.

\section{Purposes of Zoning Law: Accommodating Conflict of Interests through Zoning Regulations}

The U.S legal system has an overarching contribution in introducing, and applying the 'law of zoning'. ${ }^{25}$ Zoning is "... a method of procedure whereby municipal corporations need to control the uses or the occupancy of land or lots by restricting such land or lot to certain enumerated uses or to certain types of structures". ${ }^{26}$ First, it should be underlined that zoning is a method or a tool for implementing a procedure. The methodological concerns deal with the procedures themselves. Second, it is practised by municipal corporations

${ }^{24}$ See, for example, Slavka Zeković (2015), 'Planning and Land Policy Tools For Limiting Urban Sprawl: The Example of Belgrade', Spatium No. 33, pp. 69-75.

${ }^{25}$ David W. Craig, (1960), 'Zoning Law', University Of Pittsburgh Law Review, Vol. 22: pp. 191-199.

${ }^{26}$ See, for example, W.L. Pollard (1931), 'Outline of the Law of Zoning in the United States', The Annals of the American Academy of Political and Social Science, (Sage Publications, Inc.), Vol. 155, Part 2: Zoning in the United States, pp. 15-33. 
connoting that zoning is decentralized and practiced by local actors. Third, its overall purpose is controlling the use or occupancy of land. Fourth, there are embedded restrictions for each use of land. Fifth, the restrictions are expected to be specifically enumerated to certain land uses or specific types of structures.

As Burke notes, Zoning separates or divides municipalities into districts, regulating buildings and structures, nature and extent of their use within each district in which the districts are set for particular uses to "serve the general welfare". 27 Zoning considers "future growth and development, adequacy of drainage and storm sewers, public streets, pedestrian walkways, density of population, and many other factors that are within legislative competence". ${ }^{28}$ Similarly, "[1] and use and zoning law" regulates the use and development of public and private real estate ${ }^{29}$ which constitutes the "most common form of land-use regulation". ${ }^{30}$ Moreover, zoning controls the manner of production and appropriation of the built environment. ${ }^{31}$

The merits of zoning relate to certainty and land use conformity, while caveats are also forwarded in relation with certain features of zoning such as complexity and rigidity. There should thus be clarity with regard to the implementation of zoning ordinances based on clear principles ${ }^{32}$ because flexibility and predictability are the two opposite edges embedded in applying zoning ordinances. ${ }^{33}$

${ }^{27}$ See the Free Dictionary citing Barlow Bruke (2002), Understanding the Law of Zoning and Land Use Controls. Newark, N.J.: Lexis Nexis. Available at <https://legaldictionary.thefreedictionary.com/Zoning+law>. Accessed on 20 December 2017.

${ }^{28}$ Ibid.

${ }^{29}$ See the definition from Find Law, available at <http://hirealawyer.findlaw.com/choosingthe-right-lawyer/land-use-and-zoning.html>. Accessed on 22 Dec, 2017.

${ }^{30}$ Ibid.

${ }^{31}$ See Luciana Corrêa do Lago (2006), 'The instruments for urban reform and the ideal of citizenship: the current contradictions' In B. Stiftel, V. Watson and H. Acselrad (eds.), Dialogues in Urban and Regional Planning: Volume 2. Routledge, London \& New York.

${ }^{32}$ See, for example, N. Alfasi (2006), 'Planning policy? Between long-term planning and zoning amendments in the Israeli planning system'. Environment and Planning A 38, 553-68.

${ }^{33}$ D. L. Elliott (2008), 'A Better Way to Zone: Ten Principles to Create More Liveable Cities'. Island Press, Washington, DC. 


\subsection{Purposes of zoning or rezoning}

Zoning has important purposes. First, governments use industrial zoning “....to attract new industrial plants to the community and its environs". ${ }^{34}$ It may be used as a tool to attract investment while the industries may not be compatible with the land use pattern of neighbouring individuals, interest of communities, and environmental sustainability. Governments may use zoning to offset their public costs and this type of zoning is called 'fiscal zoning'. ${ }^{35}$ For example, zoning may be used to attract investors for "improvement of the local fiscal situation" and this was found to negate the "maintenance of a desirable land-use pattern". ${ }^{36}$ Thus, zoning requires proactive, careful and prudent balance.

Second, zoning can also be used as a tool to balance interests through rational land use allocation. The environmental, social wellbeing and economic developments of the actors can be secured. In industrial settings, it helps to create and maintain a suitable environment for the expansion and construction of new facilities. ${ }^{37}$ Land governance in general and the 'scheme of land use planning law' in particular through zoning tools can help to bring 'rational allocation of urban land resources' among different uses. ${ }^{38}$ It can help to implement the equity dimension of land use among inter and intra land use classifications. Each land use category is also regulated uniformly. ${ }^{39}$

Third, the nuisance theory brings the question why zoning is devised as a tool and who can benefit from such zoning schemes. The term 'reciprocal' denotes that zoning facilitates balance of interests and brings win-win benefits for interested parties. The home owner is, for example, protected against nuisance, and the businessperson is also protected from 'industrial intrusions' ${ }^{40}$ Beyond the individualist perspectives, there can be nuisance against collective interests and it can be detected through different mechanisms. US experience as far back as one hundred years illustrates the middle ground. ${ }^{41}$

\footnotetext{
${ }^{34}$ American Society of Planning Officials for the National Commission on Urban Problems (1969), 'Industrial Zoning and Beyond: Compatibility through Performance Standards', Research Report 2, Journal of Urban Law, 46. 723, p. 724.

${ }^{35}$ Id,, p. 69, citing Montgomery County Council v. Shiental, 238 A.2d 912 (Md. 1968).

${ }^{36}$ Ibid.

${ }^{37}$ See for example, Glen D. Corder et al. (2014), 'The Status of Industrial Ecology in Australia: Barriers and Enablers', Resources 2014, 3, 340-361 available at <www.mdpi.com/journal/resources> last accessed on 22 Dec, 2017.

${ }^{38}$ See American Society of Planning Officials for the National Commission on Urban Problems, supra note 34, p. 725.

${ }^{39}$ See William A. Fischel. (2015), Zoning Rules! The Economics of Land Use Regulation, Cambridge, Massachusetts: Lincoln Institute of Land Policy, 416+xiv. ISBN: 9781558442887.

${ }^{40}$ See W.L. Pollard, supra note 26, p. 17.

${ }^{41}$ Ibid.
} 
The efforts to avoid reciprocal nuisance can decline and be sidelined. There can also be problems attached with 'spot zoning'; 'gradual nibbling'; 'excessive land speculation'; undermining zoning principles and more political interferences. The absence of zoning at pre-development stage and implementing it later are some of the problems and challenges in the avoidance of nuisance and in applying zoning ordinances in general. ${ }^{42}$

Fourth, zoning may be introduced to promote an industrial ecology among industries and may work better in industrial parks and zones. It is preceded by sustainable spatial planning. ${ }^{43}$ Industrial ecology is a broader concept and it is now taken as a branch of systems science for sustainability, or a framework for designing and operating industrial systems so that there can be sustainable harmony with natural systems. ${ }^{44}$ It seeks to balance industrial production and economic performance with emerging understandings of local and global ecological constraints. $^{45}$

Fifth, zoning is a tool to create industrial symbiosis that serves as a tool to spread innovative green growth by fostering "eco-innovation and long-term cultural change". 46 The establishment of eco-industrial parks helps to achieve industrial symbiosis ${ }^{47}$ thereby promoting sustainable development by increasing the economic benefits and improving the environmental performance of industrial areas simultaneously. ${ }^{48}$ For instance, in the US, the first legislative approach on utilization of resources for greater efficiency and supply was adopted with incentives to promote "recycling, reduce consumer waste, and increase production of domestic energy sources". 49 Zoning is conducive to functional industrial system and it is "....a strategic policy tool for economic

${ }^{42}$ Hugh R. Pomeroy (1931), 'County Zoning under the California Planning Act', The Annals of the American Academy of Political and Social Science, Vol. 155, Part 2: Zoning in the United States, pp. 47-59.

${ }^{43}$ Elisa Conticelli and SimonaTondelli (2014), 'Eco-Industrial Parks and Sustainable Spatial Planning: A Possible Contradiction?'Adm. Sci., 4, pp. 331-349.

${ }^{44}$ R.A. Frosch and N.E. Gallopoulos (1989), 'Creating Systems Solution for Sustainable Development through Industrial Ecology: Strategies for manufacturing', Indigo Development Scientific American, pp. 144-152.

${ }^{45}$ Ibid.

${ }^{46}$ Lombardi and Laybourn (2012), 'Redefining industrial symbiosis', J. Ind. Ecol. 16 (1), pp. 28-37.

${ }^{47}$ Ilda Mannino et al. (2015), 'The decline of eco-industrial development in Porto Marghera', Italy, Journal of Cleaner Production 100, pp. 286-296.

${ }^{48}$ Ibid.

${ }^{49}$ John W. Ragsdale, (1980), 'Ecology, Growth and Law', California Western Law Review, Vol. 16, p. 243. 
development, green growth, innovation and resource efficiency". ${ }^{50}$ Industrial symbiosis starts from the policymaking (e.g. zoning) and evaluation of ecoindustrial park projects before their commencement to wastewater treatment and management, energy efficiency, solid waste management, and interorganizational relations. ${ }^{51}$

Sixth, zoning has a significant role in the accommodation of conflict over space. As Scott Campbell notes, there is the need to assure that land use balances economic, environmental, and social interests in the context of sustainability. ${ }^{52}$ Land use planning law and zoning should be applied in an integrationist and multimodal approach with nature by ensuring integration and harmony between environmental regulations and zoning ordinances. Both may be referred as laws of sustainability.

Moreover, land acquisition (based on planning and zoning) should further be subject to performance requirements (in the form of restrictions and responsibilities). In this regard, the multiple modes and methods across scales can assure land use sustainability in an integrated way amidst huge surge of investments. ${ }^{53}$ Restrictions directly aim at securing the economic, environmental and/or societal dimension of the property rights. It is to be noted that the interface between rights and restrictions occurs in the context of democracy and social order. ${ }^{54}$ However, problems may arise where the role of planners is not given due attention which can render the legal regime's objectives loose and shallow.

The framework here-below shows the points of intersection among resources, property rights, and development questions. While sustainable development may be taken as the balance in the triangular relationship among the three (environment, economic and social) components in the context of good governance (as a cross-cutting enabler), the existing conflicts are represented by the lines that need to be regulated at the junctures where there are contentious relations. Planners should thus accommodate the social, economic and environmental dimensions.

\footnotetext{
${ }^{50}$ Ibid.

51 Ibid.

${ }^{52}$ Scott Campbell (1996), 'Green Cities, Growing cities and Just Cities? Urban planning and the contradictions of sustainable development,' Journal of the American Planning Association, Vol. 62 No.3, p. 297.

${ }^{53}$ Craig Anthony and Tony Arnold (2011), 'Fourth-Generation Environmental Law: Integrationist and Multimodal', Wm. \& Mary Envtl. L. \& Pol'y Rev., Vol. 35:771-886

${ }^{54}$ Joseph William Singer (2014 ), 'Property as the Law of Democracy', Duke Law Journal, Vol. 63, pp. 1287.
} 


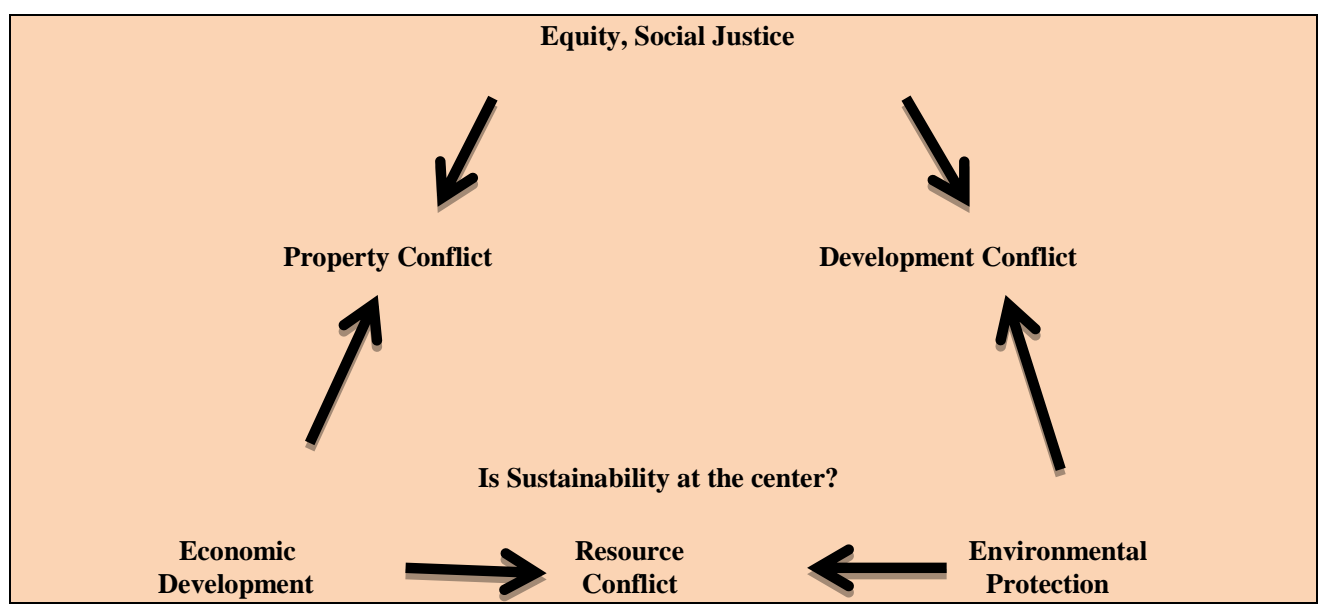

Figure 2: Adopted from Scott Campbell (1996), Planners address three fundamental priorities and three resulting conflicts.

The tendency to attain economic and social goals inherent to land use planning through multimodality can result in conflicts. The level, nature and motives of the social goals that may result in conflict should be curtailed. For instance, there can be "....obvious conflict of social goals inherent in land use planning law: regional versus local, public interest versus private rights, conservation versus change, quality versus quantity, and identity versus diffusion". 55 Such conflict between conservation and change is aggravated by the scarcity of urban land for industrial growth and the difficult task of preserving "land for the purpose designated on a land use plan in competition with free market forces". 56

The case studies in India, South Africa and China have shown similar experience. ${ }^{57}$ Multimodality by itself may not effectively achieve the desired goals or outcomes where there are self-contradictory modes or methods, or if they undermine the overall resilience. Zoning laws should thus make sure that the multimodality does not weaken the ordinances, because they should rather reinforce each other.

The overall purpose is to avoid vulnerability and enhance resilience. The ability of future generations to utilize resources should not be curtailed. Resilience holds all interests, and it strikes the balance between economic

\footnotetext{
55 American Society of Planning Officials for The Nat'l Commission on Urban Problems, supra note 34, p. 725.

${ }^{56}$ Id., p. 726.

${ }^{57}$ Etienne L. Nel \& Christian M. Rogerson (2013), Special Economic Zones in South Africa: Reflections from International Debates, Urban Forum, Springer, 24:205-217.
} 
growth with social responsibility through good governance and ethical practices that respect human rights, traditions and cultures of individuals. It is also regarded "... as an operational tool for recognizing, improving and measuring corporate responsibility" ${ }^{58}$ Resilience aims to balance the "inextricable relationship between social wellbeing, economic development, and environmental sustainability". 59 It can be used as a tool to assess zoning, land acquisition mechanisms, and performance requirement laws and practices in the context of their role in promoting the balance of land use sustainability.

\subsection{Stages of handling zoning, police power of the state and implications}

The role of the law to bring regulatory and normative standards may be promoting either law of sustainability or unsustainability. The "... maximum regulatory flexibility for the benefit of the private industrial developer and securing optimal psychological and physiological protection for the community from pollutants, effluents, and other irritants traceable to industrial activity...." are stated as the two dominant themes of industrial land use control and planning law in general.. ${ }^{60} \mathrm{~A}$ new industrial development zone may be designated and established on a newly planned plot of land without reconstructing the urbanizing purposes of particular plot of land. Zoning can be done for a newly urbanizing area before mistakes are done in planning of land uses. Zoning at this stage, it becomes "foundational rather than reconstructive",61 and it is regulated and applied mainly on the 'pre-development stage'. ${ }^{62}$

On the contrary, the reconstructive type of zoning is premised on the assumption that "[w] hatever the validity, novelty, and glamour of long range planning, land use plans and implementing controls are not always farsighted". ${ }^{63}$ This renders "rezoning of non-conforming land uses" inevitable. ${ }^{64}$ Land use plans and controls are often marked by impermanency.

${ }^{58}$ Kauko Viitanen et al (eds.) Stig Enemark (2010), 'Hanoi Declaration on Land Acquisition in Emerging Economies', International Federation of Surveyors (FIG), FIG Publication No. 51.

${ }^{59}$ FIG (2008), 'Costa Rica Declaration, Pro-Poor Coastal Zone Management', FIG Publication No 43 available at <http://www.fig.net/pub/figpub/pub43/figpub43.htm> last accessed on 23 December 2017.

${ }^{60}$ Roger A. Cunningham (1965), 'Land Use Control -The State and Local Programs', 50 IOWA L. Rev, pp. 367-413

${ }^{61}$ Pomeroy, supra note 42.

${ }^{62}$ Id., p. 52.

${ }^{63}$ American Society of Planning Officials for the National Commission on Urban Problems, supra note 34 , p. 727.

${ }^{64}$ See the definition of zoning and land use: <https://www.justia.com/real-estate/zoning-andland-use/>. Accessed on Dec. 12, 2017. 
In regulating zoning (pre-development) and rezoning (reconstructive) stage, the state ensures enforcement. The power may be granted by legislative bodies, courts or other executive organs. The 'Euiclid vs. Ambler' case was a landmark Supreme Court decision in the US that lifted the bar for the necessity of constitutional review of zoning ordinances exercised by the state's constitutional police power. ${ }^{65}$ But before this, California State had promulgated an enabling act in 1917 known as 'Zoning Enabling Act' ${ }^{\text {'6 }}$ which granted constitutional power or 'procedural act' to undertake zoning. ${ }^{67}$ The existence of such reasonable legislation enables the state to protect the health, morals, public safety, and the general welfare of community. ${ }^{68}$

The scope, breadth, extent of the police power of a state can have implications on private property, land use sustainability and striking the balance of interests. Rezoning ordinances and compulsory land acquisitions by the state can bring negative implications if the state can make discretionary decisions. "[I]f regulation goes too far, it will be recognized as a taking". 69 Though the state is given the police power to promote public good through zoning ordinances and land-use restrictions, the balance of public interests and private property interests should be kept intact. ${ }^{70}$ This has to promote due process requirements and avoid arbitrary deprivation of private property. ${ }^{71}$ It is to be noted that "... public interest is best served if the basic power to interfere with private development decisions is lodged with a unit of local self-government", ${ }^{72}$ that his falls under the police power of a state (to avoid nuisance) mostly taken as a justifiable act. $^{73}$

${ }^{65}$ Eliza Hall (2000), 'Divide and Sprawl, Decline and Fall: A Comparative Critique of Euclidean Zoning', University of Pittsburgh Law Review, Vol. 68, p. 915.

${ }^{66}$ Pomeroy, supra note 42, p, 49 Citing Ch. 734 Stats, 1917, Act 994 Deering's General Laws of California.

${ }^{67}$ Ibid.

${ }^{68}$ American Society of Planning Officials for the National Commission on Urban Problems, supra note 34, p,725, citing C, Woodbury, The Future Of Cities And Urban Development 107-13 (1953).

${ }^{69}$ Daniel A. Himebaugh (2011), 'Tie Goes to the Landowner: Ambiguous Zoning Ordinances and the Strict Construction Rule', The Urban Lawyer, Vol. 43, No. 4, p, 1062.

${ }^{70}$ Id., p. 1074.

${ }^{71}$ Id., p. 1062, citing San Diego Gas \& Elec. Co. v. City of San Diego, 450 U.S. 621, 652 (1981).

${ }^{72}$ American Society of Planning Officials for the National Commission on Urban Problems, supra note 34, p. 724, citing American Law Institute (ALI), A Model Land Development Code (Tent. Draft No. I 1968).

${ }^{73}$ Id., p,735 Citing 272 U.S. 365, 380-81, 387-88 (1926). 


\section{FDRE Laws of Zoning and Planning, Land Acquisitions and Performance Requirements}

\subsection{FDRE Constitution}

Ethiopia is a Federal state composed of nine regional states and two city administrations. ${ }^{74}$ Issues of power divisions and principles of shared rule and self-rule are addressed under the Constitution. ${ }^{75}$ The Federal government has the power of formulating and implementing policies, strategies, and plans in all economic, social and development matters of the country. ${ }^{76}$ It enacts laws for the utilization and conservation of land and other natural resources. ${ }^{77}$ It establishes and implements national standards and policy criteria specifically on health, education, science, technology, in protecting cultural and historical legacies. ${ }^{78}$ It also formulates and executes foreign investment policies and strategies. ${ }^{79}$

The Federal government enacts legal frameworks on the utilization and conservation of land. ${ }^{80}$ There can be a difference between utilization and use if the Amharic version atekakem stands for utilization. The rules and principles govern the regional states and city administrations. With regard to planning and zoning, the Federal government has the power to "formulate and implement" policies, strategies and plans of land utilization (beyond the power of enacting legal frameworks).

However, the specific application of land use regulation may be implemented by the respective regional organs. Foreign investors that operate in any of the regional states are first expected to be governed by land use legal frameworks, policies, strategies and plans that are formulated by the Federal government. Each respective region and city administration is obliged to implement laws such as the FDRE Urban Planning Proclamation No. 574/2008, and the Federal government has the duty to supervise their implementation. However, there is the need for national land use policy that can offer directions that are necessary in the interpretation and application of such laws.

The Constitution entrusts regional states with the power of administration of "land and other natural resources". ${ }^{81}$ However, they are expected to be consistent with the Federal laws. They have the concurrent power to formulate

\footnotetext{
${ }^{74}$ FDRE Constitution Proclamation No.1/1995, Art 47.

${ }^{75}$ Id., Art $51 \mathrm{ff}$.

${ }^{76}$ Id., Art 51(2).

${ }^{77}$ Id., Art 51(5).

${ }^{78}$ Id., Art 51(3).

${ }^{79}$ Id., Art 51(4).

${ }^{80}$ Id., Art 51(11) and Art 55.

${ }^{81}$ Id., Art 52(2)(d).
} 
and execute policies, strategies, plans of social, economic and development matters of the state. ${ }^{82}$ This is meant to formulate context based policies, strategies, and plans of each regional state. One of the reasons for the enactment of the Federal Urban Planning Proclamation is to replace the over-centralized planning system by the "prevailing spirit of decentralization". ${ }^{3}$ The Proclamation balances the federal structure and the role of the urban centers to prepare and implement plans. ${ }^{84}$ In this regard, the Federal government's designation of industrial parks under the land industrial park law (in disregard to the power of land administration given to regional states) was questioned by members of the parliament. ${ }^{85}$

Each region has constitutional power to prepare and implement zoning laws, policies, and strategies and plans if they are consistent mainly with the Federal land utilization legal frameworks, policies, strategies, and plans. The FDRE Urban Planning Proclamation requires urban plans (including structure plans and local development plans) to be approved by the respective Federal organs. ${ }^{86}$ The regional government or the Federal government may, according to the Proclamation, suspend any urban plan that does not comply with the principles of urban planning stated therein. ${ }^{87}$ The Proclamation gives first priority to the national development plan, then to regional development plans and finally to urban plans of each urban center. ${ }^{88}$

In general, there are still constitutional questions on what land administration is, whether planning and zoning are part of land administration activities and the implications to the hierarchal considerations stated under the Proclamation. There are concerns on why the Federal government took the power of the regional states to administer land (through upward delegation) with a view to facilitate one stop shop services of permits and licenses. ${ }^{89}$ Such tendency to

\footnotetext{
${ }^{82}$ Id., Art 52(2(c).

${ }^{83}$ FDRE Urban Planning Proclamation No. 574/2008, paragraph four of the preamble.

${ }^{84}$ Ibid.

${ }^{85}$ The Reporter, 'MPs Challenge the Constitutionality of the new industrial bill draft, available at $<\mathrm{https}$ ://archiveenglish.thereporterethiopia.com/content/mps-challengeconstitutionality-industrial-park-draft-bill $>$ Accessed on 15 Feb, 2018

${ }^{86}$ FDRE Urban Planning Proclamation 574/2008, Art 16(1).

${ }^{87}$ Id., Art 16(2).

${ }^{88}$ Id., Art 7.

${ }^{89}$ In Gambella, the federal government took the power of land administration through an upward delegation.
} 
centralize land administration seems to be in tension with the Constitution and the jurisdiction of administration under the investment proclamation. ${ }^{90}$

The other relevant Constitutional issues include the right of citizens to be consulted prior to any development project, enhancement of basic needs, strengthening the capacity of citizens and sustainable development, and the right to get remedy for any loss encumbered by any intervention made by the government. $^{91}$ These rights envisage the balance of interests in the course of promoting the social, economic and environmental objectives stated under the Constitution. $^{92}$

\subsection{Defining and characterizing zoning in Ethiopia}

Ethiopia has no comprehensive, codified, and standardized law of zoning that are directly or indirectly embodied in land use planning and administration policies and laws of the Federal and regional governments. ${ }^{93}$ One of the information kits, for example, includes the laws that target at FDI attraction and industrial development zones. ${ }^{94}$ The laws also define 'industrial development zone' (but not zoning) as a ground for analysing issues of zoning.

The Industrial Park Proclamation No. 886/2015 addresses various issues. The "transitory provision" states that any existing (i.e. pre-June 2015) industrial zones or information parks are presumed to be industrial parks on the condition that they meet the "designation criteria" and are governed by the Industrial Park proclamation. ${ }^{95}$ Previous agreements concluded between governments and industrial zones, developers, or operators are expected to be governed by this new Proclamation. Changes and developments in defining and characterizing industrial park can be observed from the relevant proclamations. ${ }^{96}$

Art 2(17) of the Investment Proclamation No. 769/2012 defines "industrial development zone" as follows:

Industrial development zone means an area with distinct boundary designated by the appropriate organ to develop identical, similar and interrelated industries together or to develop multi-faceted industries based on a plan fulfilling infrastructures such as road, electric power and water and having

${ }^{90}$ FDRE Investment Proclamation No. 769/2012 Art 4(4). After listing the types of investors and nature of investments that fall under the jurisdiction, it states a residual power or jurisdiction of regional organs. It does not mention the issue of land administration.

${ }^{91}$ FDRE Constitution Proclamation No.1/1995, Articles 43 and 44.

${ }^{92}$ Id.. Articles 89 and 90.

${ }^{93}$ See for example, David W. Craig, supra note 25.

${ }^{94}$ See for example, GRIPS (2015), 'Ethiopia Information Kit for Japanese Investors', p, 14 available at <http://www.grips.ac.jp/forum-e/af-growth/ > Accessed on 16 Dec. 2016.

${ }^{95}$ FDRE Industrial Park Proclamation No. 886/2015, Art 33.

${ }^{96}$ FDRE Investment Proclamation No. 769/2012; Investment (Amendment) Proclamation No. 849/2014; Industrial Park Proclamation No. 886/2015. 
incentive schemes with purposes containing industrial development, mitigating the impacts of environmental pollution and administering the development of urbans with plan and system.

Art 2(17) of the Investment (Amendment) Proclamation embodies a slightly different definition of industrial development zone:

... with a broad view to achieving, planned and systematic, development of industries, mitigation of the impacts of environmental pollution, and development of urban centres, and includes special economic zones, industrial parks, technology parks, export processing zones, free trade zones and the likes designated by the Investment Board.

Both versions of the Proclamation envisage the clustering ${ }^{97}$ of industries, provision of infrastructures ${ }^{98}$ and incentive schemes, and state the purposes of developing industries, mitigating the impacts of environmental pollution, and development of urban centres. These definitions pursue goal based definition of industrial zones in spite of some conceptual variation. The Investment (Amendment) Proclamation states the need for 'planned and systematic' development of industries, whereas the earlier version of the provision does not include such phrase, other than expressing the purpose of 'industrial development' without such qualifying phrases or terms.

Industrial development zones are defined based on their categorical and homogenizing factors. As Morocco's experience indicates, industrial zones can be classified as de jure and de facto. ${ }^{99}$ Industrial zones that are designated and established by law were considered as de jure, while the ones that gradually evolved without a specific regulatory ordinance were considered as de facto industrial zones.

The Investment Incentives Amendment Regulation states the possibility for the existence of private and public industrial development zones. ${ }^{100}$ However,

${ }^{97}$ Id., “... to develop identical, similar and interrelated industries... ."

${ }^{98}$ GRIPS, supra note p. 49. It is stated that there is under-developed transport infrastructure and interruption of power supply... .

${ }^{99}$ H. Stein (2009), 'Africa, Industrial Policy and Export Processing Zones: Lessons from Asia'. The first draft was prepared for the Third Meeting of the Africa Task Force, Initiative for Policy Dialogue (Columbia University), Addis Ababa, Ethiopia 10-11 July, 2008: <www.oxfordscholarship.com/view/10.1093/>. Accessed on Dec. 18, 2016. Stein states that “....exemption from duties on imported intermediate goods, raw materials and equipment when output is sold abroad, taxation and industrial regulations are typically more generous than elsewhere in the country."

${ }^{100}$ FDRE Investment Incentives Amendment Regulation No. 312/2014 
the Industrial Park law recognizes joint ownership with the government. It specifically defines an industrial park as follows: ${ }^{101}$

Industrial Park means an area with distinct boundary designated by the appropriate organ to develop comprehensive, integrated, multiple or selected functions of industries, based on a planned fulfillment of infrastructure and various services such as road, electric power and water, one stop shop and have special incentive schemes, with a broad view to achieving planned and systematic, development of industries, mitigation of impacts of pollution on environment and human being and development of urban centers, and includes special economic zones, technology parks, export processing zones, agro-processing zone, free trade zones and the like designated by the Investment Board.

First, it is an area with a distinct boundary. This envisages the Industrial Zone's conformity with an indicative list of structure plans. Second, it should be designated by the appropriate organ. Third, it should develop comprehensive, integrated (connoting industrial symbiosis), multiple or selected (similar with special economic zones) functions of industries. Fourth, it requires the fulfilment of planned infrastructures and services. Fifth, the specific types of industries that can be established potentially are listed illustratively by giving the power of designation to the Investment Board. Furthermore, the regulation that is enacted on the basis of the Proclamation states the possibility of designating "specialized industrial parks". ${ }^{102}$ It should be noted that agroprocessing zones are designated as industrial parks.

The necessity or purpose of designating industries in a "planned and systematic development" can be derived from the wordings of the definition. ${ }^{103}$ First, they are designated for mitigating environmental pollutions and their impact on human beings. However, the potential conflict on natural resource or "resource conflict" is wider and should have been addressed. Second, the designation is required to bring "development of urban centers". ${ }^{104}$ The fifth paragraph of the preamble states the purpose of the Proclamation to create job opportunities and sustainable economic development. ${ }^{105}$

The Urban Land Lease Holding Proclamation No. 721/2011 does not define zoning, but rather defines manufacturing industry premise. ${ }^{106}$ However, the

\footnotetext{
${ }^{101}$ FDRE Industrial Park Proclamation No. 886/2015, Art 2(1)

${ }^{102}$ FDRE Industrial Parks Council of Ministers Regulation No 417/2017, Art 6

${ }^{103}$ FDRE Industrial Park Proclamation No. 886/2015, Art 2(7)

${ }^{104}$ Ibid.

${ }^{105}$ Id., Fifth paragraph of the preamble.

106 See Article 2(19) which defines manufacturing industry premise as "plots of land reserved, developed or allotted in accordance with the land use plan, for the purpose of manufacturing industry".
} 
Tigray Regional Directive on "Industrial Zone" No, 01/2014 of Regulation No. $76 / 2013$ (as subsidiary law of the land lease holding system) defines industrial zone based on its nature: ${ }^{107}$

A land prepared for private and governmental industries by the appropriate organ with supportive infrastructures for the same or similar mutually benefitting clustered industries and related investments including services such as schools, hotels, hospitals, shops and other necessary services considering the expansion of industries.

This definition exemplifies the need for infrastructure and social services. It also states that the expansion of industries should be considered in the allocation of land for such purposes. Clustering of industries and promoting industrial ecology seek to balance industrial production and economic performance amidst emerging problems of local and global ecological constraints. ${ }^{108}$

In general, the above definitions on industrial parks partially and implicitly involve issues of sustainability but the degree of focus to land use sustainability seems to be inadequate. The defining elements and the purposes of most definitions tend to give more attention to the package of incentives to investors. This seems to primarily target at facilitating the catching up pursuit of investment plans.

\subsection{Rationales, objectives and principles of the laws}

\subsubsection{Urban planning law}

The urban planning law refers to the Urban Planning Proclamation No. $574 / 2008$ and the standards and manuals ${ }^{109}$ of MoUDH (Ministry of Urban Development and Housing). The rationales ${ }^{110}$ of the Proclamation are stated in its preamble. First, it aspires to regulate and guide the proliferation of unplanned urban centers by sound urban plans. Second, it envisages integrated developments among the different Federal and regional units.

Third, it calls for adherence to a participatory approach in initiating, preparing, and implementing all urban plans based on national standards. The public can effectively participate in all efforts of local development plans in the context of local settings without deviating from the national standards. Fourth, there is a need to regulate public and private development undertakings that are

\footnotetext{
${ }^{107}$ Tigray National Regional State Industrial Zone Directive No. 01/2014, Art 2(1).

${ }^{108}$ Frosch and N.E Gallopoulos, supra note 44.

${ }^{109}$ FDRE MoUDH Urban Planning, Sanitation and Beautification Bureau, Rivers and River Buffer Green Infrastructure Design Standard Implementation. Manual No. 17/2016.

${ }^{110}$ Preamble, FDRE Urban Planning Proclamation No. 574/2008,
} 
not detrimental to the general wellbeing of the local communities and environmental protection.

Fifth, the Proclamation envisages the issuance of laws that recognize the decentralization of urban planning and all local development plans that are meant to be practised in the local setting based on urban plans. This is similar with the global comparative experiences that local development plans are decentralized and practised in local settings. ${ }^{111}$ Unlike the definitions and purposes of industrial park law, highlighted here-above, the rationales of Ethiopia's urban planning law (i.e., Proclamation No. 574/2008) promotes sustainability and balances interests including the pursuance of meaningful participatory approach in line to the Constitution.

\subsubsection{Industrial park law}

The Industrial Park Proclamation has a subsequent regulation ${ }^{112}$ that applies to industrial parks designated by the Federal government. ${ }^{113}$ Article 5 of the Proclamation states its main policy objectives. ${ }^{114}$ The law has the purpose of regulating the designation, development and operation of industrial parks. The other objectives include contribution towards technological and infrastructural development, encouraging the participation of the private sector in manufacturing and 'related' investments, the enhancement of the country's competitiveness in economic development, creation of job opportunities and the enhancement of sustainable economic development.

\subsection{Zoning and planning vis-à-vis land use sustainability}

\subsubsection{Planning law}

Article 11(3)(a) of the Urban Planning Proclamation stipulates that "any local development plan shall state, as may be appropriate, zoning of use type, building height and density ...". Article 8 of the Proclamation recognizes two types of urban plans, i.e., the "city wide structure plan", and the "local development plan". The structure plan is different from the local development plan and the law sets some characterizing elements. ${ }^{115}$ It is holistic and indicates the entire plan of the city with clear boundary and sets basic physical development requirements to be fulfilled for producing coherent social,

${ }^{111}$ See, for example, Krzysztof Gawroński et al. (2010), 'Spatial Planning in the United States of America and Poland', Commission of Technical Rural Infrastructure, Polish Academy Of Sciences, Cracow Branch, pp. 53-69.

${ }^{112}$ FDRE Industrial Park Regulation No. 417/2017

${ }^{113}$ FDRE Industrial Park Proclamation No. 886/2015, Art 3.

${ }^{114}$ Id., Article 4(1-5),

${ }^{115}$ Urban Planning Proclamation No. 574/2008, Art 9. 
economic, and spatial spheres of the urban development. ${ }^{116}$ The structure plan is expected to indicate:

... the magnitude and direction of the urban growth, principal land use classes; housing development; the layout and organization of major physical and social infrastructure; redevelopment intervention requiring areas of the urban center; environmental aspects; industry zone. ${ }^{117}$

Although the law stipulates the principal land use classes manifesting the classification of land uses, the "industry zone" needs to be indicated. Housing developments, social infrastructure and environmental aspects indicating the social and environmental dimensions are clearly addressed. However, there are gaps in relation to urban redevelopment interventions; and the magnitude and frequency of acquiring land and undertaking redevelopment interventions needs to be regulated and standardized. It seems impossible to make any change before the expiry of ten years unless the changes are predicted and indicated in the structure plan.

The period of validity does not seem to accommodate land use through sustainable accommodation of interests. It can be argued that it is possible to accommodate the dynamism of socio-economic, environmental and other political driving forces. Yet, the culture of predictable and comprehensive planning should be strengthened in tandem with other relevant policies. The pace of urbanization, the urban-rural linkage and the expansion of urban centers should be accommodated in the structure plan. Such gaps have been conducive to problems such as urban sprawl, informal land holdings, conflicts, and unutilized land holdings. These challenges result from administrative failures to accommodate various economic concerns through timely expansion of administrative boundaries and landholding conversions. These failures affect the efforts to bring sustainable use of land.

It is to be noted that redevelopment interventions can affect sustainable investments and land use sustainability. This can cause uncertainties among the investors. The cost of making frequent redevelopment interventions based on the structure plan even in line with the validity period by itself can be uneconomical to the government, the victims and other concerned actors.

The other type of plan is the "local development plan", and it is an extension of the structure plan. These plans add specificity to each local context and need. ${ }^{118}$ They are expected to depict "... medium term, phased, and integrated

\footnotetext{
${ }^{116}$ Id., Art 9(1).

${ }^{117}$ Id., Art 9(2).

${ }^{118}$ Id., Art 11.
} 
urban upgrading, renewal, and expansion activities of urban area". ${ }^{119}$ Such plans facilitate the implementation of the general and broader structure plan with special focus on "strategic areas". 120

With regard to the social and environmental dimension of the local settings, the law requires the indication of "....green areas, open spaces, water bodies" and other places destined for common utilization. ${ }^{121}$ These are said to be open access resources attached to land. ${ }^{122}$ However, this should be supported by detailed regulatory framework that addresses the challenges of the "tragedy of the commons" in which aggravated depletion, degradation and scarcity may be inhibited. $^{123}$ The overall status of the law seems partially positive to maintain sustainability. However, the discretionary power in setting validity periods and frequent development interventions can affect land use sustainability.

\subsubsection{Zoning and rural-urban linkage: 'Peri-urban' as a failure in planning to accommodate urbanization}

Urban-rural linkages foster social, economic and environmental cohesions. However, there are problems of urban bias ${ }^{124}$ and failures to accommodate and enable the urbanization process supplemented by institutional, legal and policy frameworks. The failure is usually attributable to gaps in the accommodation of dynamism and the speed of urbanization and industrialization processes.

The failure to expand the boundary of any urban center in a predictable manner and accommodate the dynamism can result in changes of land use patterns and demands. There can be disturbance to established land use patterns in rural and urban areas. This is (more or less) related with the ideological orientation of the ruling elite in the pro-rural vs. pro-industrial discourse. ${ }^{125}$ The pursuit to promote investments can affect rural land use patterns. In line with the definition of an "urban center" under the urban planning law, it is either an

\footnotetext{
119 Ibid.

${ }^{120}$ Ibid.

${ }^{121}$ Id., Art 11(3) (f).

${ }^{122}$ See, for example, Peter Ekbäck (2009), 'Private, Common, and Open Access Property Rights in Land -An Investigation of Economic Principles and Legislation', Nordic Journal of Surveying and Real Estate Research Vol. 6, Issue 2, pp. 57-74

${ }^{123}$ G. Hardin (1968), 'The Tragedy of the Commons', Science 162, pp,1243-1248.

${ }^{124}$ Michael Lipton (1977), Why Poor People Stay Poor: Urban Bias in World development, Cambridge, MA: Harvard University press.

${ }^{125}$ See also Ashutosh Varshney (1993), 'Introduction: urban bias in perspective', in Beyond Urban Bias', pp. 3-22) available at: <www.tandfonline.com/doi/abs/10.1080/00220389308422293> Accessed on 8 Feb, 2018.
} 
established municipality or a locality that holds a minimum population of 2,000 inhabitants; and $50 \%$ of the population is engaged in non-agricultural labour. ${ }^{126}$

It should be noted that industrial zones (de facto or de jure) are mostly designated in peri-urban areas in Ethiopia. ${ }^{127}$ For instance, the existing industrial development zones and industrial parks of the country are developed in the periurban areas. However, the practice of designating such industrial zones or parks is done without predictable and comprehensive land use plan and zoning. The power of city administrations in this regard is discretionary thereby enabling them to freeze the development of such areas or make use of the land sustainably with progressive planning.

Government organs tend to freeze the development of such areas while there are natural and dynamic social, economic, and environmental forces and consequences caused by the forces of urbanization and industrialization processes. The major reason is usually prospective expropriation of land at any time against the payment of low amount of compensation based on different expropriation and compensation schemes under the dichotomized (urban and rural) land laws of the country. ${ }^{128}$ This shows the inclination to economic pursuits at the expense of social wellbeing and land use sustainability and may cause triangular conflicts (resource, property and development conflicts).

'Peri-urbans' are linked to the growing and expanding urbanization while administrative jurisdictions remain static. Therefore, the failure to dynamically respond through the legal, institutional and administrative mechanisms to rapid urbanization and the failure to accommodate such expansive urbanization directly and/or indirectly affects the efforts in promoting land use sustainability. Frequent, unplanned and unmanaged redevelopment interventions (similar to issues of rezoning) may disturb the sustainability dimension of land uses, the environment and social wellbeing. ${ }^{129}$ Zoning laws should thus accommodate these issues and should respond dynamically in creating integrated urban-rural linkages.

\footnotetext{
${ }^{126}$ FDRE Urban Planning Proclamation No. 548/2008 Art 2(8).

${ }^{127}$ See, for example, Idris Mohammed et al. (2017), 'Urbanization in Ethiopia: Expropriation Process and Rehabilitation Mechanism of Evicted Peri-Urban Farmers' (Policies and Practices), Nt J Econ Manag Sci 6: 451

${ }^{128}$ FDRE Expropriation of Landholdings for Public Purposes and Payment of Compensation Proclamation No. 455/2005.

${ }^{129}$ See, for example, Daniel A. Himebaugh, supra note 69.
} 


\subsubsection{Industrial park law}

The land for industrial park is to be designated by the Investment Board on the basis of planning and zoning laws. However, the law does not state on how industrial parks should be zoned, and it rather cross refers to the land use and planning laws. The term designation or 'aseyayem' (in Amharic) has an implication on planning and zoning issues. In the process of "designation and modification", the law requires that the Board should consider "compatibility with master plan, land use and the like". ${ }^{130}$ The laws of planning shall, in effect, apply to zoning of industrial parks. Likewise, the issue of "modification" of an industrial park cross refers to the theoretical discussion on reconstructive (rezoning) stage or the issues of upgrading or renewal of plans and their pertinent provisions under the Urban Planning Proclamation.

\section{Land Acquisition Mechanisms and Implications to Land Use Sustainability}

\subsection{Urban planning law}

The Urban planning Proclamation defines development as the "... carrying out of building, engineering works, mining or other operations on or below ground, or the making of any substantial change in the life of any structures or neighborhoods". ${ }^{131}$ Although the change in structures is qualified as "substantial", 132 there can be subjectivity in interpreting what constitutes substantial change of a structure.

Such changes require authorization and in spite of some prohibitions, ${ }^{133}$ they may have negative implications on sustainability. The change in land use will first affect the land itself. It will then affect the biodiversity and social wellbeing. This can be aggravated by frequent redevelopment interventions that cause the depletion, pollution and degradation of natural resources.

There are guiding principles relevant to the processes of authorizing development activities or land acquisitions. ${ }^{134}$ First, the Urban Planning Proclamation holds the principle of ensuring the "economic and sustainable use of land". ${ }^{135}$ Second, it requires that projects that are "... likely to have major environmental repercussions...." need to be ascertained by an environmental impact assessment. ${ }^{136}$ However, the words 'environmental repercussion' are

\footnotetext{
${ }^{130}$ FDRE Industrial Park Proclamation No. 886/2015, Art 25(2)(d)

${ }^{131}$ FDRE Urban Planning Proclamation No. 548/2008, Art 24

${ }^{132}$ Ibid

${ }^{133}$ Id., Art 25

${ }^{134}$ FDRE Urban Planning Proclamation No. 548/2008, Art 26

${ }^{135}$ Id., Art 26(1)

${ }^{136}$ Id., Art 26(2)
} 
vague, and specific reference should have been made to the requirement of environmental impact assessment by the concerned authorized organs. Thus the statement seems soft and it contravenes the environmental impact assessment law. ${ }^{137}$ Third, basic infrastructure should be provided in conformity with urban plans during land allocation for purposes of development. ${ }^{138}$

\subsubsection{Expropriation: Land acquisition for public purpose and land reserve}

With regard to land rights of investors, the Constitution states the government's duty to ensure "...the right of private investors to the use of the land on the basis of payment arrangements established by law". ${ }^{139}$ However, the Constitution allows expropriation of "private property" for public purposes. ${ }^{140}$

Under the seventh part of the Proclamation, there are some rules on how land acquisition for public purpose, "development freeze", acquisition for land reserve may be carried out. Amidst different land acquisition mechanisms, the urban centers are given the "rights and duties" to acquire land for two purposes. ${ }^{141}$ First, it is where the urban centers believe that it is necessary "to be used or reserved" for activities of development aligned with public purposes. Second, it is where they believe that "land reserve" is necessitated for failures related with "....uncertainty of urban planning and the implementation process...". ${ }^{142}$ However, the word "uncertainty" can give discretionary power to urban centers and this may cause inefficiency and inequity in allocating and making use of land.

In the process of expropriation, there are violations of rights in Ethiopian urban centers. ${ }^{143}$ Expropriating land should not be the norm, and there should be a culture of designing a predictable and sustainable land use planning. ${ }^{144}$ The interpretation given to public purpose is broad, and there are gaps in public participation (in spite of the preamble). Nor is there adequate judicial or

${ }^{137}$ FDRE Environmental Impact Assessment Proclamation No. 299/2002, Art 12 has incorporated issues of "Implementation Monitoring". Art 3(1) and Art 5 of the Proclamation require any development project to undertake an environmental impact assessment.

${ }^{138}$ FDRE Urban Planning Proclamation, Art 26(3)

${ }^{139}$ FDRE Constitution Proclamation No1/1995, Art 40(6)

${ }^{140}$ Id., Art 40(8) of the FDRE Constitution.

${ }^{141}$ Id., Art 52(1).

${ }^{142}$ Id., Art 52(2).

${ }^{143}$ See, for example, Muradu Abdo (2015), 'Reforming Ethiopia's Expropriation Law', Mizan Law Review, Vol. 9, No. 2. DOI: dx.doi.org/10.4314/mlr.v9i2.3

${ }^{144}$ FDRE Expropriation of Landholdings for Public Purposes and Payment of Compensation Proclamation No. 455/2005. The preamble recognizes the intensity of urbanization and the necessity of redevelopment. 
legislative involvement in determining whether a specific development project fulfills the public purpose element. ${ }^{145}$ It is rather subjective and likely to be influenced by political and economic reasons. This indeed has its own implications on the social, economic, and environmental dimensions of land and the interaction with investments.

\subsubsection{Development freeze}

The other contestable provision relates to the issue of "development freeze". 146 The law defines development freeze as the temporary stoppage of land development. It states three conditions to 'freeze' development where there is a "...preparation, revision, or modification of urban plans". ${ }^{147}$ It is temporary stoppage but it can be subjective and the subsequent regulation should restrict the regulatory organs from undertaking discretionary interventions and developments. ${ }^{148}$

The law states two conditions under which the chartered cities or urban administrations may freeze development activities after considering future impediments that are likely to happen. Here, the law favors the organs to decide on their discretion by looking whether an impediment may likely happen from "development or demolition" measures in applying a newly prepared, revised or modified urban plan. ${ }^{149}$ The other condition is where the organs believe that an increase in value may exist for an area planned to be expropriated because of current development interventions and subsequent changes in land utilizations. $^{150}$

This encourages government organs to resort to development freeze to decrease the amount of compensation. This can be done to avoid future increased compensation of peri-urban landholders. Expansions occur in periurban areas even if they are not envisaged under urban structure plans and local development plans. This aggravates the problems of urban sprawl and entails social and economic consequences. The land will remain undeveloped if freezing the development takes unreasonably long time. The period of freezing development should thus be temporary and for a reasonable period of time, in addition to which the discretion of government should be restricted. ${ }^{151}$

\footnotetext{
${ }^{145}$ Id., Art 13, It is the Wereda Administration

${ }^{146}$ FDRE Urban Planning Proclamation No. 574/2008, Art 48.

${ }^{147}$ Ibid.

${ }^{148}$ See, for example, Donald C. Shoup (1970), 'The optimal timing of urban Land

Development', Papers of the Regional Science Association, Volume XXV, University Of California, pp. 33-40.

${ }^{149}$ FDRE Urban Planning Proclamation No. 548/2008, Art 49(1).

${ }^{150}$ Id., Art 49(2).

${ }^{151}$ Tesfaye Asfaw (1991), 'An overview of Ethiopia's planning experience', The Ethiopian Economy: Structure, Problems and Policy Issues, pp. 251-262. Addis Ababa. See also,
} 


\subsubsection{Land reallocation}

The other instance in which the law allows land to be acquired is through land reallocation mechanisms. ${ }^{152}$ It is on the basis of three conditions. First, it consists of sub-dividing a plot and reallocation to create suitability “ $\ldots$ in terms of accessibility, size, location, and provision of basic infrastructure as well as ensure efficient and economical land utilization". ${ }^{153}$ This implies that the intervention in the process of reallocating land or the objective, per se, may target at efficiency while other purposes such as ensuring equity and sustainability may be at risk. These are mostly done to attract investors or to create conducive environment for investment. ${ }^{154}$ Second, the law states restriction of activity to optimize "land resource for public purpose in urban center...". ${ }^{155}$ However, this seems comparable with fiscal zoning, ${ }^{156}$ and the effort to redefine optimization again falls into the maximalist definition of public purpose. ${ }^{157}$

Third, it is also stated that reallocating or readjusting efforts need to assure compatibility with the existing urban plans. ${ }^{158}$ The use of both terms such as land reallocation and readjustment do not hold the same meaning and spirit. The holistic definition and characteristic of land readjustment is different from land reallocation. ${ }^{159}$ In view of the persistent challenges of urban sprawl and other planning problems in Ethiopia, the particular conditions and procedures of land reallocation and readjustment ${ }^{160}$ should be addressed by a regulation which is not yet issued for almost a decade.

Donald C. Shoup (1970), supra note 163, p, 12. "More properly, only "windfall" changes in the value of land, which arise because of imperfectly foreseen events that affect future development potential, should be considered speculative gains."

${ }^{152}$ FDRE Urban Planning Proclamation, Art 45.

${ }^{153}$ Id., Art 45(1).

${ }^{154}$ See for example, Nancy Lozano-Gracia et al.(2013), 'Leveraging Land to Enable Urban Transformation, Lessons from Global Experience', Policy Research Working Paper 6312, The World Bank, Sustainable Development Network Urban and Disaster Risk Management Department.

${ }^{155}$ FDRE Urban Planning Proclamation No. 548/2008, Art 45(2).

${ }^{156}$ American Society of Planning Officials for the National Commission on Urban Problems, supra note 34, p. 728. The only purpose is economic or financial one: Fiscal Zoning.

${ }^{157}$ Muradu Abdo, supra note 143, p, 306, He argues that the laws have "maximalist perspectives".

${ }^{158}$ FDRE Urban Planning Proclamation No. 548/2008, Art 46.

${ }^{159}$ See Kauko Viitanen et al. supra note 58. Land readjustment “....aims to repurpose the physical allocation of land into modern social and business uses e.g. through schemes for urban renewal and downtown developments."

${ }^{160}$ FDRE Urban Planning Proclamation, Art 47. 
In general, the land acquisition schemes that can be used by the government with the objective of promoting, protecting and guaranteeing investment flows in such an unbalanced manner can negatively affect the efforts to promote land use sustainability. This is indeed the case in the peri-urban areas where green segments and forests are cleared and expropriated to promote manufacturing and irrigation based investments. ${ }^{161}$

\subsection{Industrial park law}

The industrial park law states different land acquisition mechanisms. The government acquires land and then arranges lease holding system for investors. There are three actors in industrial park land transactions. First, it is the industrial park developer which can be any profit making public, private or public-private "developer". ${ }^{162}$ It includes the Industrial Parks Development Corporation. ${ }^{163}$ The main role of the industrial park developer is to design, construct or develop industrial parks in line with the Proclamation, regulation, the investment permit or the agreement that it has entered into. ${ }^{164}$ The industrial park operator is "any profit making enterprise". ${ }^{165}$ It is an enterprise that engages in promoting or maintaining industrial park. The industrial park enterprise is public, private and public-private enterprise jointly owned by Ethiopians and foreigners, or owned individually by each of them. ${ }^{166}$

An enterprise may possess a developed industrial park land through sublease, rent, or by building a factory within an industrial park for manufacturing or service delivery. These land acquisitions for industrial parks are mostly made in the "peri-urban areas". The balances in rights, restrictions and responsibilities have their own implications to ecological sustainability, natural capital and balancing of interests.

Restrictions are essential for effective management of land use, ${ }^{167}$ and the definitions on restrictions and responsibilities should be favorable to the environment and justified by the 'police power' of the state. ${ }^{168}$ The need for

${ }^{161}$ See for example, Achamyeleh GashuAdam (2014), 'Peri-Urban Land Tenure in Ethiopia, Doctoral Thesis in Real Estate Planning and Land Law, Royal Institute of Technology (KTH), Stockholm, Sweden.

${ }^{162}$ FDRE Industrial Park Proclamation No. 886/2015, Art 2(10).

${ }^{163}$ Id., Art 2(9). The 'corporation' means the Industrial Park Development Corporation established under Council of Ministers Regulation No. 326/2014.

${ }^{164}$ Id., Art 2(10).

${ }^{165}$ Id., Art 2(11).

${ }^{166}$ Id., Art 2(12).

${ }^{167}$ Stig Enemark (2007), 'Property Rights, Restrictions and Responsibilities: A Global Perspective', Paper Presented at Histoire De Voir Le Monde, Quebec, Canada, p. 3.

${ }^{168}$ Daryn Mcbeth (1996), 'Public Need and Private Greed: Environmental Protection and Property Rights', I Drake J. Agric. L.., Vol. 1:112. 
restrictions may not apply only to the right holders but it can also be applied to the government. ${ }^{169}$ It may add certainty to the right holders and may limit governments from undue interventions. ${ }^{170}$

The Urban Land Lease Proclamation No. 721/2011 is one of the laws relevant to industrial parks. The Proclamation does not even mention the word environment although some of the pillar principles can impliedly apply to the environment. For example, the issue of public interest may be an opportunity to integrate environmental issues and restrictions to land holders. One may also raise the issue whether the government can go beyond restrictions and take private land holdings to conserve or preserve environmental interests. This is known as green grabbing. ${ }^{171}$ However, the law does not incorporate such express element other than usage of the generic phrase 'other purpose'. ${ }^{172}$

The other most related law to industrial parks is the Federal Rural Land Administration and Use Proclamation No. 456/2005 and the respective regional laws. The Proclamation incorporates provisions under the third chapter titled 'Rural Land Use Restrictions'. The Proclamation states the need to develop land use planning, proper use of sloppy, gully, and wet lands ${ }^{173}$ and proper strategy that facilitates the "utilization of rural land for villagization and other social services". ${ }^{174}$ A farmer may not cultivate land having 30 degree slope and without putting terraces on the land. ${ }^{175}$ Another concern is whether the existing restrictions on water use rights are excluded by the industrial park law as they

${ }^{169}$ See, for example, Rohan Bennett et al (2005), 'Achieving Sustainable Development Objectives through Better Management of Property Rights, Restrictions \& Responsibilities', Expert Group Meeting on Incorporating Sustainable Development Objectives into ICT Enabled Land Administration Systems, 9-11 November 2005, Centre for Spatial Data Infrastructures and Land Administration, The University Of Melbourne, Australia.

${ }^{170}$ See for example, Jerrold A. Long (2012/13), 'Waiting for Hohfeld: Property Rights, Property Privileges, and the Physical Consequences of Word Choice', Gonzaga Law Review, Vol. 48, p. 2.

${ }^{171}$ James Fairhead et al (2012), 'Green Grabbing: A New Appropriation of Nature?' Journal of Peasant Studies, 39:2, pp. 237-261.

${ }^{172}$ See FDRE Urban Land Lease Holding Proclamation, Articles 2(7) and Art 25(1)(b). The Proclamation provides that leasehold may be terminated where the use of the land is destined 'for other purpose due to public interest'.

${ }^{173}$ FDRE Rural Land Administration and Use Proclamation 456/2005, Article 13.

${ }^{174}$ Id., Article 14.

${ }^{175}$ Id., Article 13(4). 
are mostly treated as annexes to land laws. This has negative implication on the prioritization of rights stated under the pertinent water laws. ${ }^{176}$

The FDRE Criminal Code embodies criminal responsibilities against acts such as contamination of water by any harmful substance even if it is committed negligently. ${ }^{177}$ Other examples of criminal responsibility relate to the contamination of pastureland (Art. 518), environmental pollution (Art. 519), and 'mismanagement of hazardous waste and other materials (Art. 520).

\section{Performance Requirements for Industrial Parks: Land Use Sustainability and Striking the Balance of Interests}

After land is acquired by the government, especially in the peri-urban areas, it will be leased to the developer and subleased to the operator or the enterprise. After land acquisition, the law restricts transfer of land which is not developed in order to prevent speculation. ${ }^{178}$ In this regard, the law empowers the Investment Board to take action against any leasing or sub-leasing of land to other third parties in violation of laws and agreements. ${ }^{179}$ It also empowers the Board to make "annual fair market lease value" to discourage unlawful enrichments through speculative transactions.

With regard to the social dimension, there are standards on employment related requirements. There is a requirement of focus on employees who are nationals and due attention is given to the provision of specialized trainings and knowledge transfer. The Industrial Parks Regulations requires a "tripartite modality" to bring specific standards and procedures (regulations) and it states the composition of tripartite committee. ${ }^{180}$ The committee is composed of "... Ministry of Labour and Social Affairs, the Ministry of Industry, industrial park developer, operator or enterprise and employees' representatives." This composition should be examined in light of ILO standards. ${ }^{181}$ The relevant government bodies should indeed monitor the fulfillment of the expectations including job creation, because the land acquisition is made at the expense of the local people.

${ }^{176}$ Zbelo Haileslassie (2016), 'The Quest for Standard Tests in Prioritizing Water Use Rights in Ethiopia: Reasonable Use, Beneficial Use or 'Beyond', Mizan Law Review, Vol. 10, No.1, pp. 177-216. DOI: dx.doi.org/10.4314/mlr.v10i1.6

${ }^{177}$ See FDRE Criminal Code Proclamation No. 414/2004, Art 517.

${ }^{178}$ FDRE Industrial Park Proclamation No. 886/2015, Art 5(6).

${ }^{179}$ Id., Art 11(1\&2).

${ }^{180}$ FDRE Industrial Park Regulation No. 417/2017, Art 35.

${ }^{181}$ The International Labour Organization (ILO) Convention No. 144 in 1976, entitled the Tripartite Consultation (International Labour Standards) Convention, available at www.ilo.org. 
Based on the peculiar features of an industrial park, the law, as an exception, allows negotiation for labor contract or temporary work. ${ }^{182}$ However, this is problematic to the labor force since it creates job insecurity and payment of lower amount of wage. It gives wide discretion to investors in hiring and firing employees. For example, most of the employment opportunities in Aider Industrial Zone' in Mekelle, Ethiopia are casual, temporary and seasonal.

The law requires the enterprises or the actual investors to secure "...public order, moral, safety and security; and human health". ${ }^{183}$ However, there is a tendency in the law towards watering down restrictions by using phrases such as "....free exercise of investment activity". ${ }^{184}$ There are also other guarantees, protections and national treatment for foreign investors that are stipulated under the Proclamation. ${ }^{185}$

The regulation states that any developer is expected to submit the economic feasibility and "social and environmental impact assessment reports" of the project so that it can be allowed to "go ahead" with the project upon approval by the appropriate organs. ${ }^{186}$ The other performance requirement relates to the developer's duty to protect the environment ${ }^{187}$ and the operator's duty to observe environmental obligations. ${ }^{188}$ The enterprise should not endanger animal health and plant life. ${ }^{189}$ In general, the actors should observe environmental laws (both federal and regional) ${ }^{190}$ and the other general laws of the country. However, lack of clear (specific, measurable, operational and coherent) standards and other technical lacunae in the legal regime should be examined while cross-referring to various laws. ${ }^{191}$

In general, the Proclamation embodies the sanctions of reprimand, suspension, and revocation of permit. Reprimand will be used to rectify any violation inflicted by the developer or operator in a given period of time. ${ }^{192}$ Suspension occurs upon failure to rectify within a given period of time. ${ }^{193}$

\footnotetext{
${ }^{182}$ FDRE Industrial Park Regulation No. 417/2017, Art 28(2).

${ }^{183}$ FDRE Industrial Park Proclamation No. 886/2015, Art 9(3).

${ }^{184}$ Ibid.

${ }^{185}$ Id., Arts 19-21.

${ }^{186}$ FDRE Industrial Park Regulation No. 417/2017, Art 5(8) (c).

${ }^{187}$ Id., Art 5(7).

${ }^{188}$ Id., Art 8(1) and 8(6)

${ }^{189}$ Id., Art 9(3).

${ }^{190}$ Id., Art 24(1).

${ }^{191}$ FDRE Environmental Pollution Control Proclamation No. 300/2002.

${ }^{192}$ FDRE Industrial Park Proclamation No. 886/2015, Art 30(1(a)).

${ }^{193}$ Id., Art 30(1(b)).
} 
Ultimately, revocation can ensue under any one of the following four conditions. ${ }^{194}$

First, the cause for revocation of permit may be false information to acquire the permit. This can be attached with haphazard investments and the weak capacity of the responsible organs to trace the problems on spot while delivering "one-stop shop services". Second, the permit may be revoked if the land is left undeveloped and not administered. However, there is no specific duration that can be used as threshold for failure to develop land. ${ }^{195}$ Third, the investor may terminate its activities upon notification to the appropriate organ. The fourth ground for revocation is where the investor is declared bankrupt. Upon revocation of investment permit, the land will be returned to the leasor. ${ }^{196}$

Similar administrative measures may be taken by the Investment Board where any party is engaged in speculation of industrial park land. ${ }^{197}$ There are no environmental and social factors that are expressly stated as grounds for the suspension or revocation of investment permits. ${ }^{198}$ In general, the performance requirements are partial and the potential measures for non-compliance relate to the actors (developers and operators) and exclude the end-users or enterprises.

\section{Brief Empirical Evidence on the three Stages}

\subsection{Current status of the industrial parks}

Currently, there are four operational industrial parks in Ethiopia, i.e., Hawassa, Bole Lemi I, Mekelle and Kombolcha industrial parks. ${ }^{199}$ The Investment Commission has planned to establish 15 industrial parks. There is a success story of "Africa Juice Tibila Share Company" a joint venture with the Ethiopian government. The company started its operation in Tibila Farm in the upper Awash valley. There are indeed gains with regard to employment opportunities and economic benefits while land use patterns and the measures thereof are not clearly stated.

In examining the practical cases that are relevant to land use sustainability, it is better to see how the industrial parks are planned and zoned. The GTP-I was endorsed in 2010 while the Urban Planning Proclamation was promulgated in

\footnotetext{
${ }^{194}$ Id., Art 30(1-3)).

${ }^{195}$ For instance, the Rural Land Administration and Land Use Proclamation No. 456/2005.

${ }^{196}$ FDRE Industrial Park Proclamation, Art 30(3).

${ }^{197}$ Id., Art 11(1-3)).

${ }^{198}$ See for example, Dejene Girma (2012) Environmental Impact Assessment in Ethiopia: Laws and Practices, PhD Dissertation, Department of Interdisciplinary Studies, Graduate School of the University of Alabama.

${ }^{199}$ See the website of the Investment Commission:

$<$ http://www.investethiopia.gov.et/investment-opportunities/strategic-sectors/industryzone-development>
} 
2008. This massive and extensive effort for designating industrial parks was planned in GTP-II. This shows that most of the de jure industrial parks (industrial parks established after the enactment of the Industrial Park Proclamation 886/2015) were not proactively planned and zoned.

Most of the industrial parks are established in the peri-urban areas or in the rural land administration jurisdictions. It is common practice that smallholder farmers object such investment schemes. A recent story by Reuters (titled "expansion of Ethiopia's first industrial park reopens old wounds") deals with the first industrial park found in a small town called Dukem. The Chinese owned Eastern Industrial Zone occupies a very fertile land, and it has submitted an expansion request of 167 hectares which relocates more than 300 smallholder farmers.

However, this raised an angry reaction from the old wound of the farmers. One of the government's bodies has responded that an additional land will be given to 197 farmers who lost their land in 2007. The compensation was "low" and it did not include replacement of agricultural land. Although most of the current (more than 10,500) employees are from Dukem, there are complaints of low wages and poor treatment by the employers. There was a strike in one of the shoe factories and this had led to street protests.

In general, the planning and zoning of the parks seems to be unsustainable because interests were not balanced with a view to ensuring sustainable land use. It is commendable that a limited size of land was taken for inauguration, but the request for expansion involves a large area without certainty on the prospective viability and sustained competitiveness of the projects in the export market and import substitution. There is no certainty whether interests are balanced, property and resource conflicts are avoided and social and environmental justices are assured.

\subsection{Challenges from the "de facto" vs. "de jure" industrial zones}

There are areas zoned for industries and these are commonly called "industrial zones". As highlighted earlier, the Industrial Park Proclamation considers industrial zones established before its enactment (i.e. 2015) as industrial parks if they fulfill the criteria and have similar nature.

For instance, there is commonly known "industry zone" in the Northern part of Mekelle city. The incentives include land lease with lower bidding price. However, the Tigray Industrial Zone directive excludes some of the industries that will benefit from such industrial zones. The reasons for restricting some of the manufacturing activities (such as flour, nail and steel factories) from acquiring land in such industrial zones are economic and partially social. In fact, 
some of the industries already exist in such zones established before the issuance of the directive. ${ }^{200}$

Social and environmental concerns in industrial zones include waste disposal, pollutant effluents, failure to develop land and to operate the planned manufacturing process, diversions in the use of the constructed buildings for warehousing services, the problem of speculation, lack of financial accessibility through loan arrangement from the Development Bank of Ethiopia, frequent requests for changing the planned manufacturing purpose and Environmental Impact Assessment (EIA). For example, 17 investors requested to change their investment and they were also given EIA clearance. More than $60 \%$ of the investors have not yet started to operate in line with their projects.

The performance requirements at the 'industry zone' in the Northern part of Mekelle are not observed and enforced. Most of the land acquisitions were not made based on EIA clearance. Some of them were required to prepare environmental management plans and these are mostly left unenforced in all industries since there are only two experts at city level. Likewise, in a peri-urban place called Yibabe (at the outskirts of Bahir Dar) land is designated for the construction of industrial park. Although the land that was utilized for farming purposes by the local farmers was expropriated, the project is not yet implemented. It is common practice that most of the buildings of such projects are used for warehousing and other services contrary to the plans stated in the investment proposals.

\section{Conclusion}

Zoning facilitates the creation of similar land use patterns and the imposition of restrictions in the form of performance requirements. Zoning law accompanies land use law and it regulates private and public land development. It regulates standards of compliance. The arguments against zoning (such as complexity and rigidity) should not be taken as hindrance in the application of zoning regulations that are required in predictable and well-managed developments.

The absence of land use policy in Ethiopia has aggravated the problems in land use sustainability that balances interests by avoiding the resource, property and development conflicts. The haphazard 'laws' of zoning and planning are not supported by comprehensive planning. Ethiopia does not have comprehensive and standardized zoning laws although there are incidental references of zoning in various laws that are enacted to regulate other purposes.

Although the industrial parks law inclines toward facilitating the catching up of investment plans that adversely affect sustainability, the rationales, principles

\footnotetext{
${ }^{200}$ Foud Sefrioui (1999), 'Industrial Zones Experience in Morocco', Journal of Economic Cooperation among Islamic Countries, 20, 1, pp. 23-70.
} 
or objectives of the urban planning law are relatively supportive to sustainability and the accommodation of interests enshrined in the FDRE Constitution. Yet, the laws on land expropriation and the broad definitions of 'public purpose' give discretionary power to the government. Prime focus is given to the allocation of land to investors in the name of efficient land utilization and economic development while the other social and environmental interests are at risk. These problems are further aggravated by the discretionary power of the government in freezing development of land on the ground of prospective development plans. The laws on land reallocation also provide wide discretionary powers to the government

The law generally adheres to an integrationist and multimodal approach in enforcing performance requirements in industrial parks. However, there are uncertainties and risks to balance interests. The law rather tends to give an expansive exercise of rights to end-users in industrial parks. With regard to labour conditions, there are substantial gaps that should be addressed. All these gaps in performance requirements are attributable to fixations on catching up pursuits.

The government's desires to catch up with extensive investment plans and programs should thus be evaluated with caution and prudence so that such pursuits do not adversely affect land use sustainability. To this end, there is a need for land use policy and zoning laws. The problems of urban sprawl should be addressed, and there should be urban-rural integrated thinking as interactive continuum under the policies, laws, institutions and administrative bodies. Equally significant are the Environmental Impact Assessment rules that should be meaningfully implemented with stronger political commitment. With regard to property conflict, most land acquisitions are done by freezing the development of the land and expropriation without fair compensation. The interests of the public at large should thus be balanced and reconciled.

Moreover, there is the need for clear and comprehensive standards of performance requirement. This envisages clear codes of conduct that can create a culture of self-regulation by the investors and a steady enhancement of corporate social responsibility. The labor related issues should be primarily initiated and enforced by the employees themselves. The tripartite modality should be fostered in manner that promotes meaningful and direct engagement of the laborers, and it should at the same time balance economic, social and environmental interests. These pillars should be envisaged and clearly articulated in the governance of performance standards in the context of a transparent and accountable governance system of investments. 